\title{
Social and Economic Conditions of West Australian Aborigines
}

$\mathrm{T}$ HE report of a Commission of Inquiry on social and economic conditions among the aborigines of West Australia and the working of the State system of protection, which was published on March 12 last, criticises strongly the inadequacy of the provision for medical attention, the inefficiency of the care for half-castes and the wasteful and unsatisfactory character of the management of the Moore River settlement. The Commissioner, $\mathbf{M r}$. II. D. Moseley, is doubtful of the success of the missions among the aborigines; and he finds that allegations of cruelty and ill-treatment of the aborigines, which have appeared in the public Press from 1930 onward, are without foundation.

In the north and north-west, natives on pastoral properties, the Commissioner reports, experience conditions which as nearly as possible approach their natural life. The work of the aborigines employed on stations takes an appropriate form, and the only criticism of the Government stations is that a greater effort should be made to keep the aborigines more constantly employed. The 'bush' natives are best left alone; and the land now occupied by them should be secured inalienably as a reserve and additional land should be set aside for reserve purposes in anticipation of closer white settlement in the northern area. The native is under no hardship through the non-payment of wages; and there is nothing approaching a condition of slavery. In the north-west, where the wage system has been in operation for some time, it has encouraged the gambling and squandering habits of the aboriginal.

To meet the inadequacy of the present medical attention available, the establishment of clinies and hospitals is recommended at four points to facilitate early diagnosis and treatment. Farther south, in the areas of closer settlement, increased hospital accommodation is recommended, the existing accommoda. tion being both inadequate and undesirable in character. In addition to providing first-aid stores, employers of labour should be required to make payment into a medical fund on account of each employee; and in this connexion the present system of licenses for labour is criticised, as it does not require particulars of individual employees to be reported, but merely the total number employed. A system of registration is therefore recommended.

In dealing with leprosy, the inadequacy of the provision for segregation of detected cases awaiting transhipment to the leper hospital at Darwin, and the delay in evacuation are strongly eriticised. It is suggested that the State should withdraw from the arrangement whereby leprosy is made a Federal concern and provide a leprosarium of its own on one of the islands off the coast; but if this is impossible, that suitable arrangements should be made for isolating detected cases, while the inspection for leprosy and venereal disease, for which agitation has been going on since 1924, should be held forthwith.

If conditions in the sparsely settled north and northwest can be regarded as satisfactory on the whole, except as regards the medical question, it is far otherwise in the more closely settled south, where the aboriginal has come more closely into contact with white civilisation, and native camps are situated in close proximity to the towns. In the Moore River settlement, children and young persons are being educated and trained in close proximity to the camps for indigent aborigines, without proper measures being taken to keep them apart; hence most undesirable results, especially as affecting young girls. The buildings are inadequate, verminous and inefficient, and proper educational equipment is lacking. The care of half-castes is thoroughly inefficient and inoperative. So far as possible, camps should not be allowed to remain near the towns. It is recommended for both able-bodied aborigines and halfcastes that a system of farm-stations should be established on which adults and parents could work on their own allotments, while the children were trained for suitable occupations. An extension of the existing arrangements for the training of girls for service and other occupations is also recommended.

In regard to the laws affecting aborigines, the most important measure suggested is the provision of special courts for the trial of 'bush' natives, in which the proceedings would be suited to the code of the native and such as he himself and the members of his tribe would understand. The holding of such courts might be part of the duties of a district protector on patrol.

It is pointed out how far the criticism of existing conditions is concerned with matters which can be attributed to the defects of the present organisation of protection, whereby the Chief Protector, assisted by more than a hundred honorary protectors, who do not function except to grant permits to employ labour, has been overburdened with office work and has been unable to travel and inspect actual conditions. A reorganisation is recommended in which the office of Chief Protector should be abolished, and his place taken by a secretary of the Department, who would be responsible for office detail, while the active work of protection would be in the hands of district protectors, of whom one, a medical man, should be appointed to the northern area forthwith.

\section{The Collection of Dew}

\section{By H. E. Becketr and A. F. Dukton}

$\triangle$ RISING from the serious shortage of water in A many districts during the summers of 1933 and 1934, the suggestion was made that the collection of dew would be profitable and that research should be undertaken into the economic design of dewponds. A little consideration showed that certain types of roofs, suitably insulated underneath, might act as economical and efficient collectors of dew.

If 'dew ponds' really do collect dew owing to the cooling either of the water surface or of the surrounding banks below the dew point, by radiation to the night sky, even more dew should be collected on a thin metal roof of low thermal capacity, provided that the roof has an efficient radiating surface and is prevented from gaining heat from below.

In order to find whether sufficiently low temperatures could be obtained on thin metal sheets and to what extent these temperatures were affected by 